\title{
EPIDEMIOLOGY OF SPINE FRACTURES IN MOTORCYCLE ACCIDENT VICTIMS
}

\author{
EPIDEMIOLOGIA DAS FRATURAS DA COLUNA VERTEBRAL EM VÍTIMAS DE ACIDENTE MOTOCICLISTTICO
}

\author{
EPIDEMIOLOGÍA DE LAS FRACTURAS VERTEBRALES EN LAS VÍCTIMAS \\ DE ACCIDENTES DE MOTOCICLETAS
}

\begin{abstract}
Tiago Argolo Bittencourt de Oliveira ${ }^{1,2}$, Sérgio Murilo dos Santos Andrade ${ }^{1}$, Gabriel Oliveira Prado ${ }^{3}$, Rony Brito Fernandes ${ }^{1,2}$, Maurício Santos Gusmāo ${ }^{1,2}$, Eduardo Gil França Gomes¹, Djalma Castro de Amorim Junior ${ }^{1,2}$, Maurício Guimaräes Pimentel ${ }^{1,2}$,

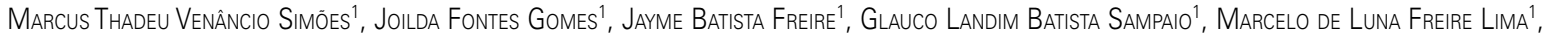
Marcos Almeida Matos ${ }^{4}$
\end{abstract}

\author{
1. Hospital Geral do Estado, Spinal Cord Trauma (SCT) Service, Salvador, BA, Brazil. \\ 2. Hospital da Santa Casa de Misericórdia da Bahia, Salvador, BA, Brazil. \\ 3. Hospital Espanhol, Orthopedics and Traumaology Service, Salvador, BA, Brazil. \\ 4. Escola Bahiana de Medicina e Saúde Pública, Salvador, BA, Brazil.
}

\begin{abstract}
Objective: To analyze the incidence of spinal injuries between 2000-2010 due to motorcycle accidents and the relation to the increase in motorcycle sales in the same period, as well as the anatomical distribution of these spinal injuries. Methods: Data were collected from 1,295 records of patients who have suffered spinal injury resulting from motorcycle accidents admitted to the ward TRM (Spinal Cord Trauma) of the Hospital Geral do Estado da Bahia from 2000 to 2010 in this retrospective study. We selected 110 medical records and collected information on sex age, neurological deficit on admission (according to Frankel scale), diagnosis, and level of injury. Results: Between 2000 and 2010 there was an increase of almost five times in the incidence of patients who have suffered spinal injury due to motorcycle accidents. More than half (51.4\%) had cervical spine injury, $37.2 \%$ thoracic spine injury and $11.34 \%$ had lumbar spine injury. Only $34.3 \%$ of patients had no neurological deficit on admission and patients with thoracic spine fracture had a higher incidence and severity of lesion. The average age of patients was 30 years. Conclusions: The increased incidence of spinal injuries due motorcycle accidents occurred in the same period in which there was an increase in motorcycle sales in the country. Patients who have suffered those injuries were young, with higher incidence in the cervical and thoracic spinal levels and high rates of neurological deficit.
\end{abstract}

Keywords: Spine; Spine fractures; Spinal injuries; Accidents, traffic; Motorcycles.

\section{RESUMO}

Objetivo: Analisar a incidência de lesões na coluna vertebral entre 2000 e 2010 devido a acidente motociclístico e sua relação com o aumento da venda de motos nesse período, assim como a distribuição anatômica dessas lesões na coluna. Métodos: Trata-se de estudo retrospectivo, no qual foram coletados dados de 1.295 prontuários de pacientes que sofreram lesão da coluna decorrente de acidente motociclístico internados na enfermaria de TRM (Trauma Raquimedular) do Hospital Geral do Estado da Bahia no período de 2000 a 2010. Foram selecionados 110 prontuários e catalogadas as informações com relação ao sexo, idade, déficit neurológico na apresentação (de acordo com a escala de Frankel), diagnóstico e nível da lesão. Resultados: Entre os anos de 2000 e 2010 houve um aumento de quase cinco vezes na incidência de pacientes que sofreram lesão da coluna devido a acidente motociclístico. Mais da metade (51,4\%) apresentou lesão na coluna cervical, 37,2\% na torácica e 11,4\% na lombar. Somente $34,3 \%$ dos pacientes não tinham déficit neurológico na admissão e pacientes com fratura da coluna torácica tiveram maior incidência e gravidade de lesão medular. A média de idade dos pacientes foi de 30 anos. Conclusões: O aumento da incidência de lesões na coluna devido acidente motociclístico ocorreu no mesmo período em que houve aumento das vendas de motos no país. Os pacientes que sofreram essas lesões eram jovens, com incidência maior nos níveis cenvical e torácico e altos índices de déficit neurológico.

Descritores: Coluna vertebral; Fraturas da coluna vertebral; Traumatismos da coluna vertebral; Acidentes de trânsito; Motocicletas.

\section{RESUMEN}

Objetivo: Analizar la incidencia de lesiones de la columna entre 2000-2010 debido a los accidentes de motocicleta y su relación con el aumento de las ventas de motocicletas en ese período, y la distribución anatómica de las lesiones de la columna vertebral. Métodos: Estudio retrospectivo en el que se recogieron datos de 1.295 registros de pacientes que han sufrido lesiones de la columna resultantes de accidentes de motocicleta ingresados en la sala de hospital TRM (Trauma de la Médula Espinal) del Hospital Geral do Estado da Bahia entre 2000 y 2010. Se seleccionaron 110 historiales médicos y se recogió información sobre el sexo, edad, déficit neurológico al ingreso (según la escala de Frankel), el diagnóstico y el nivel de la lesión. Resultados: Entre 2000 y 2010 hubo un aumento de casi cinco veces en la incidencia de pacientes que han sufrido lesiones de la columna debido a los accidentes de motocicleta. Más de la mitad (51,4\%) tuvo lesiones de la columna cervical, el 37,2\% tenían lesión en la columna torácica y el 11,4\%, en la lumbar. Sólo el 34,3\% de los pacientes no tuvieron déficit neurológico al ingreso y los pacientes con fractura de la columna torácica tuvieron una mayor incidencia y severidad de la lesión de la médula espinal. La edad promedio de los pacientes fue 30 años. Conclusiones: El aumento de la incidencia de lesiones en la columna debido a los accidentes de motocicleta se produjo en el mismo período en que hubo un aumento en las ventas de motocicletas en el país. Los pacientes que han sufrido esas lesiones eran jóvenes, con mayor incidencia en los niveles cervicales y torácicos y altas tasas de déficit neurológico.

Descriptores: Columna vertebral; Fracturas de la columna vertebral; Traumatismos vertebrales; Accidentes de tránsito; Motocicletas.

Study developed at the Hospital Geral do Estado da Bahia, SCT Service, Salvador, BA, Brazil.

Correspondence: Alameda dos Jardins, 408, Ed. Begônia, Apto 1903, Horto Bela Vista, Salvador, BA, Brazil. 41098-040. tiagoargolo@gmail.com 


\section{INTRODUCTION}

Over the last decade, Brazil has experienced a real epidemic of motorcycle accidents. The number of incidents has tripled and the number of deaths risen from 4,541 in 2001 to 14,666 in 2011. ${ }^{1}$ During the same period, the total fleet of motorcycles grew from 4.5 to 19.9 million. ${ }^{2}$ According to Vasconcelos and Ribeiro, ${ }^{3} 26 \%$ of the patients with spinal injuries in the city of Ribeirão Preto were victims of motorcycle accidents. Moreover, it was confirmed that many patients were not using safety equipment or had committed some sort of traffic violation. Motorcyclists accounted for $48.4 \%$ of the public costs of hospitalizations resulting from traffic accidents in $2012 .^{1}$

The presence of spinal injuries in a victim of polytrauma worsens the prognosis, makes recovery difficult, and increases hospitalization time, increasing hospital and social security costs. $11.2 \%$ of motorcycle accident victims suffer spinal injuries and trauma from hyperflexion of the thoracic spine is the most commonly encountered spinal injury. ${ }^{4}$ Patients with fractures at this level experience complete neurological deficit more often than with fractures of the cervical and lumbar spines. ${ }^{5}$

The objective of this study is to analyze the incidence of spinal injuries from motorcycle accidents between 2000 and 2011 and its relationship to the increase in motorcycle sales during the same period and the anatomical distribution of these spinal injuries.

\section{METHODS}

This is a retrospective study based on medical records. After approval by the ethics committee (CAAE 41289714.9.0000.0052), data were collected for all the patients (1295 medical records) hospitalized in the spinal cord trauma ward (SCT) of the Hospital Geral do Estado da Bahia, during the period from 2000 to 2010. This unit is the largest SCT service and a reference for the entire State of Bahia. The inclusion criterion was to evaluate all medical records for patients who suffered spinal injuries resulting from motorcycle accidents. Individuals who suffered injuries from other causes and those with no record of the etiology of the trauma or whose information was not clearly documented were excluded.

A hundred and ten patients were selected from the total number of cases for evaluation by the study and information regarding sex, age, neurological deficit (according to the Frankel scale ${ }^{6}$ ), diagnosis, and the level of the injury were cataloged. We verified whether there was an annual increase in the number of spinal injuries caused by motorcycle accidents and whether there was any relationship between the level of the injury and the presence of neurological deficit.

The data collected were initially presented in frequency distribution tables, using absolute numbers and percentages for discreet variables, while the continuous variables were presented as averages with standard deviation. In order to confirm statistical difference, the patients were divided into two groups: with deficit and without deficit. The groups were compared using the chi-square hypothesis test for discreet variables and the Student's t-test for continuous variables. In both cases, a value of 0.05 was used as a measurement of statistical significance.

\section{RESULTS}

Between 2000 and 2010, 110 patients were registered as victims of motorcycle accidents. In 2000, motorcycle accidents were the cause of the trauma in $5.2 \%$ of patients, rising to $17.5 \%$ in 2010 (Figure 1). In absolute numbers, this represents an increase from 5 to 24 patients during this period.

Only $1.8 \%$ of patients suffered injuries to more than one spinal segment and in $4.5 \%$ of patients the location of the injury was not documented. More than half $(51.4 \%)$ of the injuries were in the cervical spine, $37.2 \%$ were in the thoracic spine, and $11.4 \%$ were in the lumbar spine. (Figure 2)

Most patients in this study had neurological deficits and more than half had Frankel scale values of $A$ or $B(20 \%$ and $36.2 \%$, respectively), $6.7 \%$ with Frankel C, $2.8 \%$ with Frankel D, and $34.3 \%$ with
Frankel E. (Figure 3) 4.5\% of the patients had no neurological deficit documented in their medical reports.

When stratified by injury level, the patients with thoracic lesions had the highest incidence of neurological deficit at $82.1 \%$ (Table 1) and of complete spinal cord lesion at 43.6\%, (Table 2) with statistical significance $(p<0.01)$.

The vast majority of patients were male (87\%) and the average patient age was 30 years.

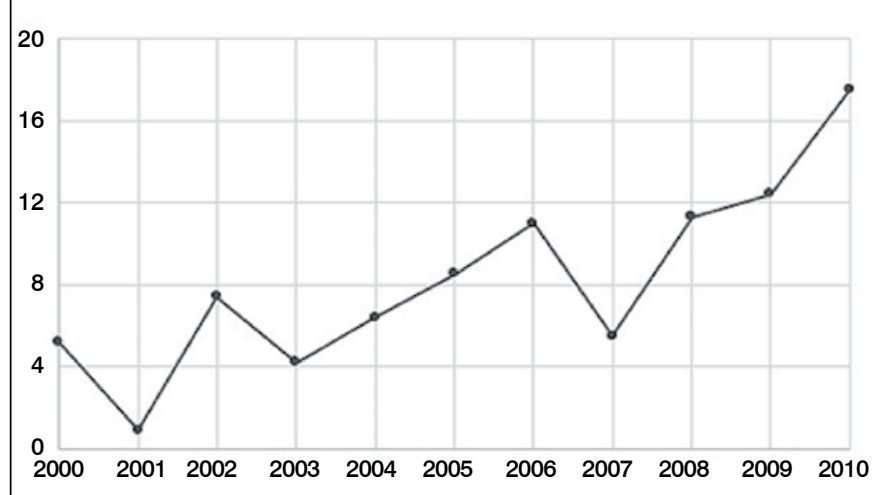

Figure 1: Percentage of patients with spinal injury from motorcycle accidents by year.

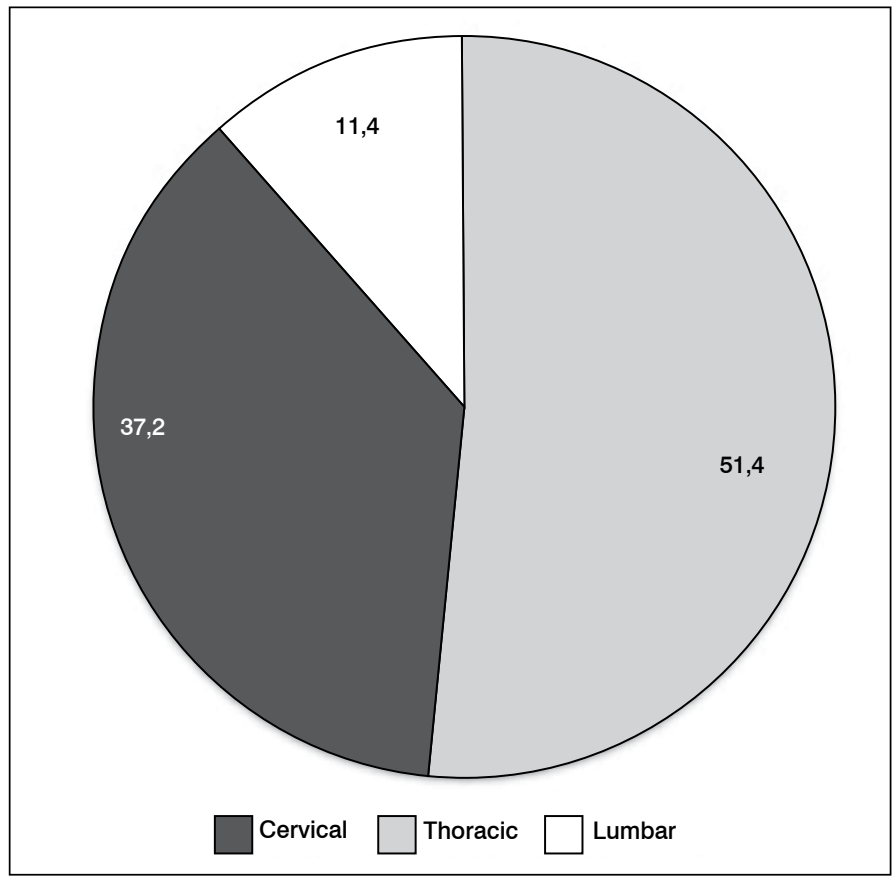

Figure 2: Anatomical distribution of injuries, by level.

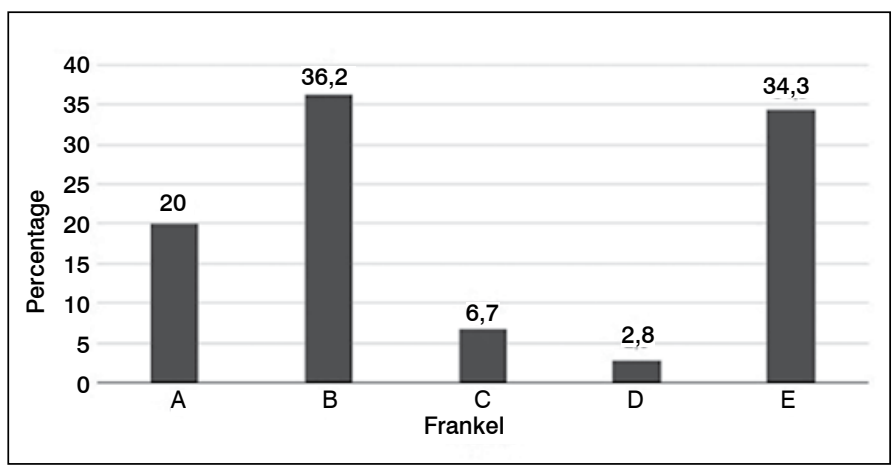

Figure 3: Distribution of neurological deficit according to the Frankel scale. 
Table 1. Incidence of neurological deficit by level of injury.

\begin{tabular}{c|c|c|c}
\hline Level of injury & With neurological deficit & Without neurological deficit & P \\
\cline { 1 - 3 } Cervical & $36(66.7 \%)$ & $18(33.3 \%)$ & \multirow{2}{*}{0.01} \\
\cline { 1 - 3 } Thoracic & $32(82.1 \%)$ & $7(17.9 \%)$ & \\
\hline Lumbar & $1(8.3 \%)$ & $11(91.7 \%)$ & \\
\cline { 1 - 3 } Total & $69(65.7 \%)$ & $36(34.3)$ & \\
\hline
\end{tabular}

Table 2. Percent distribution of neurological deficit by level of injury using the Frankel scale.

\begin{tabular}{c|c|c|c|c|c|c}
\hline Level of injury & Frankel A & Frankel B & Frankel C & Frankel D & Frankel E & P \\
\hline Cervical & 5.6 & 46.3 & 11.1 & 3.7 & 33.3 & \multirow{2}{*}{$<0.01$} \\
\cline { 1 - 6 } Thoracic & 43.6 & 33.3 & 2.6 & 2.6 & 17.9 & \\
\cline { 1 - 5 } Lumbar & 8.3 & 0 & 0 & 0 & 91.7 & \\
\hline
\end{tabular}

\section{DISCUSSION}

The thoracic spine is characteristically more stable because of the rib cage and the sternum bone, so that traumas in this region require more force to cause fractures.

According to Tator, $^{5}$ cervical and thoracic spine fractures have a higher frequency of neurological deficit due to the smaller relative spinal cord space and the thoracic spine has a higher frequency of complete spinal cord lesion. The findings were similar in our study, where we observed the existence of neurological deficit in $66.7 \%$ of the patients with cervical lesions and $82.1 \%$ of the patients with thoracic spine fractures. Complete spinal cord lesion occurred in $43.6 \%$ of the patients with thoracic fractures.

In their epidemiological study of spinal fractures, Fernandes et al. $^{7}$ showed that the most commonly fractured vertebra is $L 1$, representing $11.4 \%$ of the cases. Robertson et al. ${ }^{4}$ reported that fractures of the thoracic spine are the most predominant in mo- torcycle accidents, occurring in $54 \%$ of cases. In our study, we found a higher frequency of injuries to the cervical and thoracic spines and we confirmed that $65 \%$ of the patients experienced some degree of neurological deficit. This number is much higher than that normally found in the literature and we believe that this may be related to the fact that many patients without an indication of surgical treatment are discharged from the hospital before referral to the SCT ward. Even so, this statistic is of great concern because the consequence is an ever-increasing expense for the public health and social security systems.

In this study, we confirmed that between 2000 and 2010 there was a fivefold increase in the incidence of spinal injuries resulting from motorcycle accidents, coinciding with a 4.5 times increase in the motorcycle fleet over the same period.

In their epidemiological review of patients with spine fractures, Diniz et al. ${ }^{8}$ showed that $82 \%$ of the patients were male with an average age of 38 years. In our study, $87 \%$ of the patients were male and the average age was only 30 , representing additional costs to the social security system.

\section{CONCLUSION}

Patients who suffer spinal injuries in motorcycle accidents are generally male, young, and usually suffer fracture of the cervical or thoracic spine, with high rates of neurological deficit.

Patients who fracture the thoracic spine in motorcycle accidents have a higher incidence and severity of neurological deficit as compared to the other levels.

The incidence of spinal lesions from motorcycle accidents in Brazil increased by almost a factor of five during the same period in which there was an increase of similar magnitude in the size of the motorcycle fleet.

All authors declare no potential conflict of interest concerning this article.

AUTHOR CONTRIBUTIONS: Each author made significant, individual contributions to the development of this manuscript. TABO was the author. SMSA was the advisor. GOP helped with the writing of the text. RFP collected the data from the medical records. MSG assisted with data collection and the editing of the text. GLBS helped research the bibliographical references. MAM was responsible for statistics. EGFG was the director of the service where the study took place and DCAJ, MGP, MTVS, JFG, JBF, and MLFL were members of the spine group at the hospital where the study was conducted.

\section{REFERENCES}

1. Waiselfisz JJ. Mapa da violência 2013: Acidentes de trânsito e motocicletas. Rio de Janeiro: CEBELA; 2013. Disponível em http://www.mapadaviolencia .org.br/pdf2013/ mapa2013_transito.pdf

2. Rodrigues JM. Evolução da frota de automóveis e motos no Brasil 2001-2012 (Relatório 2013). Rio de Janeiro: Institutos Nacionais de Ciência e Tecnologia (INCT); 2013. Disponível em http://www.observatoriodasmetropoles.net/ download/auto_motos2013.pdf

3. Vasconcelos EC, Riberto M. Caracterização clínica e das situações de fratura da coluna vertebral no município de Ribeirão Preto, propostas para um programa de prevenção do trauma raquimedular. Coluna/Columna. 2011;10(01):40-3.

4. Robertson A, Giannoudis PV, Branfoot T, Baelow IF. Spinal injury patterns resulting from car and motorcycle acidentes. Spine (Phila Pa 1976). 2002;27(24):2825-30.
5. Tator CH. Spine-spinal cord relationships in spinal cord trauma. Clin Neurosurg. 1983; 30: 479-94.

6. Frankel HL, Hancock DO, Hyslop G, Melzak J, Michaelis LS, Ungar GH, et al. The value of postural reduction in the initial management of closed injuries of the spine with paraplegia and tetraplegia. Paraplegia. 1969:7(3):179-92.

7. Fernandes RB, Gomes EGF, Gusmão MS, Amorim Júnior DC, Simões MTV, Gomes JF. Estudo clínico epidemiológico das fraturas da coluna vertebral. Coluna/Columna. 2012;11(3):230-3

8. Diniz IV, Soares RAS, Nascimento JA, Soares MJG. Caracterização das vítimas de acidente de trânsito que apresentam traumatismo raquimedular. Rev Bras Ci Saúde. 2012;16(03):371-8 